\title{
ecancermedicalscience
The impact of tobacco tax/law implementation on pancreatic cancer mortality in Mexico, 1999-2015
}

\author{
Eduardo Hernández-Garduño \\ Department of Education and Health Research, Instituto de Seguridad Social del Estado de México y Municipios (ISSEMyM), Toluca, México 50080, \\ Mexico
}

Corresponding author: Eduardo Hernández-Garduño. E-mail: epidemiologist.researcher@gmail.com

\begin{abstract}
Among the multiple aetiologies identified for pancreatic cancer (PC), cigarette smoking and diabetes are considered "moderate risk factors". Analysis of PC mortality trends is important as changes in incidence and mortality of this tumour can be partially attributable to changes in smoking patterns. A recent Mexican study examined PC mortality trends and showed a favourable trend from 2000 to 2014 [1]. However, the impact of new tobacco tax/laws which were implemented in Mexico in 2007/2008 was not assessed in this study. In this re-analysis we assessed their impact on PC mortality and found a non-statistically significant trend from 1999 to 2008 - however, PC mortality statistically decreased from 2008 with an annual percent change or APC of $-1.27,-1.23$ and -1.17 in both sexes, females and males respectively, $p<0.05$. These declines are likely resulting in part from new tobacco tax/laws which are likely contributing to the decrease over time of smoking prevalence and environmental tobacco smoke exposure.
\end{abstract}

Keywords: pancreatic cancer, mortality, tobacco tax/law, smoking prevalence, pancreatic cancer risk factors.

(Cont.)

Published: 10/10/2018

Received: $27 / 08 / 2018$

ecancer 2018, 12:ed85 https://doi.org/10.3332/ecancer.2018.ed85

Copyright: (c) the authors; licensee ecancermedicalscience. This is an Open Access article distributed under the terms of the Creative Commons Attribution License (http://creativecommons.org/licenses/by/3.0), which permits unrestricted use, distribution, and reproduction in any medium, provided the original work is properly cited. 


\section{Introduction}

$\mathrm{PC}$ is among the cancers with the poorest prognosis with a 5 -year survival rate of only 5 to $7 \%$. Among modifiable risk factors, smoking is well established and one of the most important with an average increased risk for ever-smokers of $70 \%$ and an estimated population attributable fraction of 11-32\% [2]. One of the studies on the mechanism linking tobacco and PC performed on mice exposed for 20 weeks to cigarette smoke showed an increase of ADM formation and accelerated PanIN development in conjunction with decreased number of myeloid-derived suppressor cells and increase in the number of M2 macrophages and dendritic cells in the pancreas, accelerating PC progression [3].

Two recent epidemiological studies from Spain and Mexico analysed PC mortality temporal trends. The Spanish study [4] showed an unfavourable increasing trend in men from 1975 to 1986 (APC = 4.1) and from 1986 to 2012 (APC = 1.1). Corresponding APCs for women were 3.6 and 1.4 respectively. The slower increasing rate in the last period could be associated with decrease of smoking prevalence in men since the late eighties while in women prevalence rose until the late nineties and then slightly decreased [5] possibly explaining the higher APC estimate in women in the second period. Contrary to these findings, a recent countrywide Mexican study showed a favourable decreasing trend in PC mortality from 2000 to 2014 with APCs for the whole period of $-1.08,-0.89$ and -0.87 for both sexes, females and males respectively [1]. Figure 1 of that Mexican study showed a higher rate of decline from 2008 onward but the authors did not determine whether this apparent change in trend was statistically significant. In this re-analysis we employed joinpoint trend analysis [6] to determine this. This is important because a new tobacco tax and law in Mexico were implemented in 2007 and 2008 respectively [7,8].

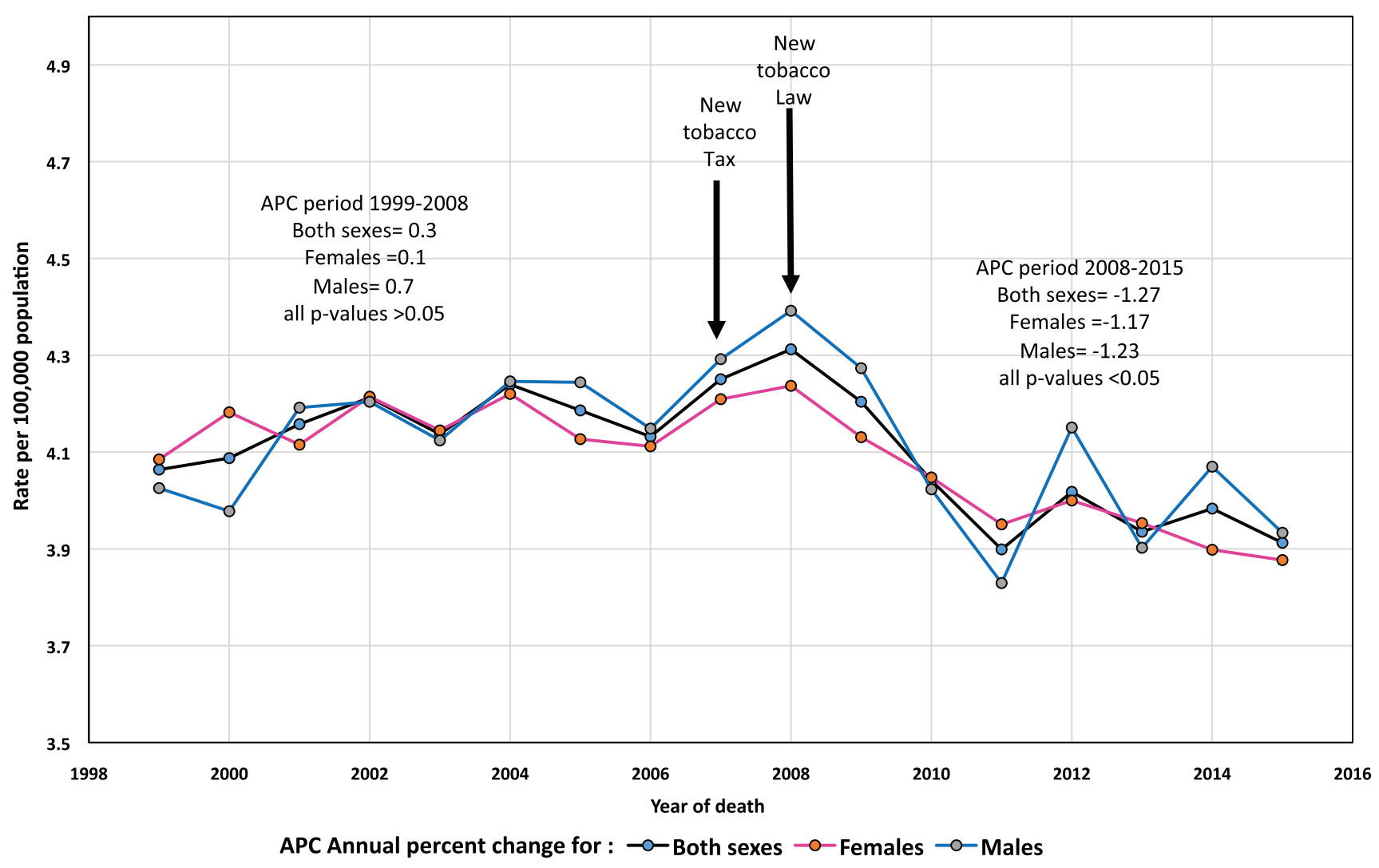

Figure 1. Age-standardised mortality rates of pancreatic cancer, all ages Mexico 1999-2015. 


\section{Pancreatic cancer mortality analysis in Mexico since the implementation of tobacco tax/law in $2007 / 2008$}

Mortality data for this re-analysis was obtained from the same source (INEGI) [9] as the previous study [1]. We increased the study time period from 1999 to 2015 because data became available. The number of PC deaths (ICD-10 ${ }^{\text {th }}$ code C25) and crude rates were calculated by year, sex and by 5-year age groups based on population growth estimates published by the "Consejo Nacional de Población" [10]. Agestandardised mortality rates (ASMR) were then calculated according to the World (WHO 2000-2025) Standard Population [11].

There were a total of 57,169 pancreatic deaths during the 17 -years study period (53.0\% females, annual mean deaths of 3,362$)$. The median ASMR of the 17-year period was 4.1 for both sexes, females and males (Table 1) with a favourable trend of ASMR-APC in the whole period $(-0.33,95 \% \mathrm{Cl}-0.6--0.1 \mathrm{P}=0.023)$ however, an increasing non statistically significant trend was found from 1999 to 2008 $(A P C=0.32,95 \% \mathrm{Cl}-0.1-0.8, P=0.10)$ but it became favourable from 2008 to 2015 in both sexes $(\mathrm{APC}=-1.27,95 \% \mathrm{Cl}-1.9--0.6$, $P=0.001$ ) with slightly higher rate of decline in females (APC: -1.23$)$ than males $(-1.17), p<0.05$, Figure 1.

Table 1. Distribution of pancreatic cancer deaths by year of death and gender, Whole country of Mexico, 1999-2015.

\begin{tabular}{|c|cc|cc|cc|}
\hline \multirow{2}{*}{$\begin{array}{c}\text { Year of } \\
\text { death }\end{array}$} & \multicolumn{2}{|c|}{ Both sexes: } & \multicolumn{2}{c|}{ Females: } & \multicolumn{2}{c|}{ Males: } \\
\cline { 2 - 7 } & $\mathbf{N}=$ & ASMR & $\mathbf{N}=$ & ASMR & $\mathbf{N}=$ & ASMR \\
\hline 1999 & 2,558 & 4.1 & 1,354 & 4.1 & 1,204 & 4.0 \\
2000 & 2,654 & 4.1 & 1,432 & 4.2 & 1,222 & 4.0 \\
2001 & 2,783 & 4.2 & 1,456 & 4.1 & 1,327 & 4.2 \\
2002 & 2,927 & 4.2 & 1,549 & 4.2 & 1,378 & 4.2 \\
2003 & 2,964 & 4.1 & 1,569 & 4.1 & 1,395 & 4.1 \\
2004 & 3,129 & 4.2 & 1,655 & 4.2 & 1,474 & 4.2 \\
2005 & 3,185 & 4.2 & 1,673 & 4.1 & 1,512 & 4.2 \\
2006 & 3,241 & 4.1 & 1,713 & 4.1 & 1,528 & 4.1 \\
2007 & 3,444 & 4.3 & 1,814 & 4.2 & 1,630 & 4.3 \\
2008 & 3,607 & 4.3 & 1,895 & 4.2 & 1,712 & 4.4 \\
2009 & 3,635 & 4.2 & 1,912 & 4.1 & 1,723 & 4.3 \\
2010 & 3,618 & 4.0 & 1,943 & 4.0 & 1,675 & 4.0 \\
2011 & 3,598 & 3.9 & 1,955 & 4.0 & 1,643 & 3.8 \\
2012 & 3,821 & 4.0 & 1,993 & 4.0 & 1,828 & 4.2 \\
2013 & 3,863 & 3.9 & 2,092 & 4.0 & 1,771 & 3.9 \\
2014 & 4,039 & 4.0 & 2,125 & 3.9 & 1,914 & 4.1 \\
2015 & 4,103 & 3.9 & 2,196 & 3.9 & 1,907 & 3.9 \\
Total & 57,169 & & 30,326 & & 26,843 & \\
Median & & 4.1 & 1,814 & 4.1 & & 4.1 \\
\hline ASMR = Age-standardised mortality rates per & & & & & \\
\end{tabular}




\section{Relevance of the temporal changes of pancreatic cancer mortality and tobacco smoking patterns}

The decline in PC mortality over time may be partly explained by the reduction of smoking prevalence. According to national addiction surveys for the years 2002 and 2016-2017 [12,13], the overall prevalence of current smokers for Mexican adults aged 18 to 65 years decreased from $27 \%$ in 2002 to $20.1 \%$ in $2016-2017$ (25\% reduction), from $42.3 \%$ to $31.3 \%$ in males ( $26.0 \%$ reduction) and from $15.1 \%$ to $9.8 \%$ (35.1\% reduction) in females. The higher reduction rate of smoking prevalence in females may explain the higher rate of decline in females' APC.

The favourable decreasing trend in PC from 2008 coincided with the implementation of an increase in cigarette taxes in 2007 [7] and legislation protecting nonsmokers from second hand smoke in 2008 [8]. Even the overall prevalence of second-hand smoke (defined in national surveys as involuntary exposure to cigarette smoke in nonsmokers with specific questions for exposure in households, work, pubs, schools, restaurants and public transportation) in all adults did not change from $2002(22.5 \%)$ to $2016-2017$ (22.6\%), it did in females, $30.7 \%$ to $21.3 \%$ respectively with $30 \%$ reduction $[12,13]$. This may have also contributed to the higher rate of APC decline in females from 2008 .

Our recent study showed a reduction in lung cancer ASMR's median in Mexicans aged $\geq 40$ years from 15.8 (1999-2008) to 13.6 (2008-2014) in females (14.0\% reduction) and from 38.7 to 28.3 in males (27\% reduction) respectively [14].This can also be attributed to implementation of tobacco tax/law and the decrease of smoking prevalence over time though the smaller reduction of female's ASMR median is attributable to the still high prevalence of wood smoke exposure from cooking which was 40.5\% in 2012/2013 in rural areas [15]. Long term wood smoke exposure has been associated with lung cancer in nonsmoking women in Mexico [16]. Future studies are needed to determine whether long-term wood smoke exposure is associated with PC.

Besides smoking, diabetes is a known risk factor associated with PC. We have recently shown that diabetes mortality decreased in Mexican females age 20 to 79 years (APC $=-0.9$ ) after the implementation of "Seguro Popular" (SP) in 2004 [17] which is health insurance offered primarily for the poor offering free diagnostics, hospitalisation, treatment and counseling for diabetes among other diseases. Better diabetes control likely explains the decrease in diabetes mortality in females and contributes to the higher rate of decline in females' PC compared to males. A positive dose response relationship between post load glycemia and PC mortality has been reported [18].

\section{Conclusion}

The decrease in PC mortality in this analysis and of lung cancer mortality in our previous study is likely attributable partly to decreasing smoking prevalence and exposure to second-hand smoke over time in Mexico. The statistically significant decreasing trend in PC mortality after 2008 confirms the effectiveness of new tobacco tax/law in Mexico. This link demonstrates the importance for assessing impacts of changes in health policy on specific health outcomes.

\section{Conflicts of interest}

The author has no conflicts to report.

\section{Funding}

The author did not receive any funding for this work.

\section{Acknowledgments}

I thank the staff of INEGI for their hard work that made this study possible. 


\section{References}

1. González-Santiago O, Yeverino-Gutiérrez ML, and Del Rosario González-González M, et al (2017) Mortality assessment of patients with pancreatic cancer in Mexico, 2000-2014 Ecancermedicalscience 11788 [doi:10.3332/ecancer.2017.788. eCollection 2017]

2. Maisonneuve $P$ and Lowenfels $A B$ (2015) Risk factors for pancreatic cancer: a summary review of meta-analytical studies Int $J$ Epidemiol 44 186-198

3. Kumar S, Torres MP, and Kaur S, et al (2015) Smoking accelerates pancreatic cancer progression by promoting differentiation of MDSCs and inducing HB-EGF expression in macrophages Oncogene $342052 \mathrm{e} 60$

4. Seoane-Mato D, Nuñez O, and Fernández-de-Larrea N, et al (2018) Long-term trends in pancreatic cancer mortality in Spain (1952-2012) BMC Cancer 18(1) 625 [doi:10.1186/s12885-018-4494-3. PubMed PMID: 29866063; PubMed Central PMCID: PMC5987643]

5. Instituto Nacional de Estadística Encuesta Nacional de Salud (serie histórica). Portal estadístico [Internet] Ministerio de Sanidad, Servicios Sociales e Igualdad [cited 30/06/2017] [http://pestadistico.inteligenciadegestion.msssi.es/publicoSNS/Comun/ArbolNodos.aspx?idNodo=17150]

6. Surveillance Research Program (2018) Joinpoint trend analysis software National Cancer Institute [Division of Cancer Control and Populaton Sciences. https://surveillance.cancer.gov/joinpoint/]

7. Ley del Impuesto Especial sobre Producción y Servicios Diario Oficial de la Federación, miércoles 27 de diciembre de 2006. Cuarta sección (México City, México: Gobierno de México, 2006), p 80

8. Ley de Protección a la Salud de los No Fumadores en el Distrito Federal Aprobada por la Asamblea Legislativa del Distrito Federal el 26 de febrero y publicada en la Gaceta Oficial del Distrito Federal el 4 de marzo de 2008 (México City, México: Gobierno de México, 2008) [http://www.ordenjuridico.gob.mx/Documentos/Estatal/Distrito\%20Federal/wo27594.pdf]

9. Gobierno de Mexico. Secretaría de Salud Dirección General de Información en Salud (2018) Bases de datos sobre defunciones (México City, Mexico) [http://www.dgis.salud.gob.mx/contenidos/basesdedatos/std defunciones_gobmx.html]

10. Consejo Nacional de Población (CONAPO) (2015) Datos de Proyecciones (México City, México) [http://www.conapo.gob.mx/es/ CONAPO/Proyecciones Datos]

11. National Cancer Institute (2016) World (WHO 2000-2025) standard population (Bethesda, MD: NCI) [https://seer.cancer.gov/stdpopulations/world.who.html]

12. Instituto Nacional de Estadística, Geografía e Informática (2002) Encuesta Nacional de Adicciones 2002 ENA 2002 [https://www. gob.mx/cms/uploads/attachment/file/238948/ENA 2002 Completo.pdf]

13. Encuesta Nacional del Consumo de Drogas, Alcohol y Tabaco (2017) Reporte Tabaco. 2016-2017 ENCODAT [https://drive.google. com/file/d/1lktptvdu2nsrSpMBMT4FdqBlk8gikz7q/view]

14. Hernández-Garduño E and Ocaña-Servín HL (2018) Lung cancer mortality trends in Mexico, 1999-2014 Salud Publica Mex 60(3) 366-369 [doi:10.21149/8730. PubMed PMID: 29746755]

15. Hernández-Garduño E, Gómez-García E, and Campos-Gómez S (2017) Prevalence trends of Wood use as the main cooking fuel in Mexico, 1990-2013 Salud Publica Mex 59 (1) 68-75 [doi:10.21149/7770. PubMed PMID: 28423112]

16. Hernández-Garduño E, Brauer M, and Pérez-Neria J, et al (2004) Wood smoke exposure and lung adenocarcinoma in non-smoking Mexican women Int J Tuberc Lung Dis 8(3) 377-383 [PubMed PMID: 15139478]

17. Hernández-Garduño E and Jimenez-Cortéz A (2017) The impact of Popular Health Insurance "Seguro Popular" on diabetes mortality in Mexico, 1999-2014 Salud Pública Mex 59(4) 494-496

18. Gapstur SM, Gann PH, and Lowe W, et al (2000) Abnormal glucosa metabolism and pancreatic cancer mortality JAMA 283(19) 2552-2558 [PubMed PMID: 10815119] 